\title{
Introduction: The Continuity and Change of Antisemitism
}

\section{Mikael Shainkman}

7 here was a time at the end of the twentieth century when antisemitism was relegated to the margins of public discourse. In the general atmosphere of increasing tolerance and fight against all kinds of prejudices and increased protection of minorities, Jews lived in security and even started to take that state of affairs for granted. Following the Holocaust, no one who wanted to be taken seriously in the Western world would accept the epithet antisemite. Prejudice and hatred against Jews, based either on ancient Christian antiJewish teachings or nineteenth-century racist theories about the inferiority of Jewish blood, disappeared together with their most vociferous propagators in the Third Reich. Anyone still clinging to the beliefs that the Jews controlled the world via a stranglehold on the media, the financial markets, and politiciansbe it on Capitol Hill, in Whitehall, or in the Kremlin — had to either hide those beliefs or express them only behind closed doors to avoid running the risk of social ostracism. The populist lies blaming the Jews for all the ills of the world lost much of their mass appeal when Allied soldiers threw open the gates of German concentration camps and revealed the unspeakable atrocities that were the outcome of Nazi antisemitic propaganda. ${ }^{1}$

1 It is telling, for instance, that books on antisemitism published at the end of the twentieth century did not treat traditional right-wing antisemitism as a current problem. Instead, these books dealt extensively with antisemitism in the Arab world, in the communist bloc, or within the Left in the West but hardly even mentioned right-wing antisemitism. See, for example, Michael Curtis, ed., Antisemitism in the Contemporary World (Boulder, CO: Westview Press, 1986). 
Also, within Christian circles, the horrors of the Holocaust gave cause for reflection and penance. Most important, the Catholic Church drastically changed its views on Judaism and the Jewish people in a way that cannot be described as anything other than revolutionary. At the Second Vatican Council in Rome, 1962-1965, church teachings on eternally continuous Jewish guilt for the death of Jesus was revoked, and the liturgical language was altered to remove words that were insulting or inciting against Jews. Furthermore, Pope John Paul II, who was a young man in Poland during the Second World War and witnessed the obliteration of his country's Jewish communities, worked hard and conscientiously during his long reign to address the antisemitic legacy of the Catholic Church. His successors on the Throne of Saint Peter, Benedict XVI and Francis, have continued this policy of rapprochement and fraternal relationship between Christianity and Judaism. ${ }^{2}$ Despite the fact that there is opposition to this policy from within conservative pockets of the Catholic Church, and from other Christian sects as well, the improvement in Judeo-Christian relations in the second half of the twentieth century is truly remarkable.

All in all, the second half of the twentieth century offered Europe and most of the rest of the Western world an almost unprecedented period of political stability, economic growth, and increasing international interdependency through transnational organizations like the United Nations, NATO, and the European Union. Thanks to the combination of unprecedented prosperity and peace on the one hand and the haunting memories of the Holocaust on the other, antisemitism seemed to be a thing of the past.

\section{THE RETURN OF TRADITIONAL ANTISEMITISM}

Unfortunately, the twenty-first century hardly had time to get out of the starting blocks before Jews around the world were disabused of that notion. In the last decade and a half, we have witnessed the return of what the eminent scholar of antisemitism Robert Wistrich called "the longest hatred." Ironically enough,

2 See, for instance, Dina Porat, Karma Ben Johanan, and Ruth Braude, eds., Ba-Et Ha-Zot: Mismakhim U-Mechkarim al Ha-Knesiyah Ha-Katolit Ve-Ha-Yehudim Lenokhach Ha-Shoah U-Ve-Ikvoteyah (Tel Aviv: Tel Aviv University Press, 2015), 80-118.

3 See, for instance, Dina Porat, ed., Antisemitism Worldwide 2001/2 (Tel Aviv: Stephen Roth Institute for the Study of Contemporary Antisemitism and Racism, 2002); Roni Stauber, "The Academic and Public Debate over the Meaning of the 'New Antisemitism," Kantor Center Position Papers (Tel Aviv: Kantor Center for the Study of Contemporary European Jewry, 2009); and US Department of State, Report on Global Anti-Semitism, July 1, 2003December 15, 2004, December 30, 2004. 
the first signs that this might in fact not be the end of either history or antisemitism came with the fall of the Iron Curtain - the very event that was supposed to herald the final victory of liberal democracy, capitalism, and a new, free world for everyone.

When the Cold War ended, old conflicts generally thought to have been dead and a part of a departed era reappeared. It soon became evident that they had not been eradicated under communism in the Soviet Union and its satellite states but merely suppressed. The newly liberated Eastern European states embraced not only free speech and capitalism but also old prejudices, irredentism, and nationalist chauvinism. The most explosive and deadly consequences were seen in the Balkans, where Yugoslavia disintegrated amid the turmoil of a bloody and savage civil war. ${ }^{4}$ Even though the development was far less dramatic elsewhere, the long, and sometimes painful, readjustment to a new political and economic system of government gave rise to populist and extreme right-wing political movements and parties. Such groups had formed already in the 1990s, but the global financial crisis of the first decade of the twenty-first century elevated them to positions of power and influence in a number of former communist countries, most notably Hungary. Among extreme rightwing nationalists in Eastern Europe, it is not uncommon to blame the Jews for the forty years of communist dictatorship and the poor economic situation that followed. 5

The fall of communism and the reintegration of Eastern Europe into the family of European nations have also forced people who lived behind the Iron Curtain to reevaluate their twentieth-century history-most notably what really happened during the Second World War and the Holocaust. Following the Soviet lead, communist countries had distorted the memory of the Nazi crimes, and the Jewish identity of the victims of the Holocaust was obfuscated, ignored, or sometimes even denied. ${ }^{6}$ For instance, historian Barbara Törnquist-Plewa talks about the "Polonisation of the Holocaust," in which the Polish Communist authorities played down Jewish suffering during the German occupation and instead emphasized Polish suffering in education, art, and museums. Auschwitz became the symbol of Polish victimhood, with a

4 Kerstin Nyström, “The Holocaust and Croatian National Identity: An Uneasy Relationship," in The Holocaust-Post-War Battlefields: Genocides as Historical Culture, ed. Klas-Göran Karlsson and Ulf Zander (Malmö: Sekel, 2006), 277.

5 Randolph L. Braham, ed., Anti-Semitism and the Treatment of the Holocaust in Post-Communist Eastern Europe (New York: Columbia University Press, 1994), 10.

6 Braham, Post-Communist Eastern Europe, 4. 
xii $\mid$ Introduction: The Continuity and Change of Antisemitism

plaque proclaiming that "four million Poles and citizens of other nations" had perished there, with no mention of the fact that some 90 percent of all those victims were Jewish. ${ }^{7}$ After the Cold War, when Poland drew nearer to Europe, especially in practical terms, and applied for membership in the European Union, this required a revision of the national narrative of the Holocaust and a critical new look at antisemitism in the country. This was a sometimes painful process with mixed results. ${ }^{8}$

Even though the situation there has been far less volatile, Western Europe has not been immune to the growth of populist extremist political movements. The financial crisis, in combination with dramatic demographic changes amid a large influx of immigrants from the third world, has fed extreme rightwing populist movements in faltering countries like Greece but also in stable democracies that by most objective standards have few reasons to worry about their economy, like those in Scandinavia. Nonetheless, extreme right-wing groups have gained momentum and electoral strength in countries like France, Germany, the Netherlands, Sweden, and many others. The extreme right in the West rages against an increasingly globalized economy, the undermining of traditional values, and the weakening of the nation. Even though most extreme right-wing politicians who draw large crowds of voters in Western Europe today tend to blame Islam and Muslim immigrants for the current woes of Europe, it should be noted that all these accusations have traditionally been pinned on the Jews, and this is increasingly the case once again-both in Europe and in the Americas. ${ }^{9}$

\section{A “NEW" ANTISEMITISM?}

Nonetheless, Western Europe has seen the emergence of a different kind of antisemitism in the past fifty, and most notably in the last fifteen, years. This form of antisemitism, sometimes called "new," is characterized by its antisemitic narrativization of the state of Israel, and in that respect it might be called new-it presents a new rationale for hating Jews. This form of antisemitism has been around for decades, but there was a sudden explosion

7 Barbara Törnquist-Plewa, "The Jedwabne Killings: A Challenge for Polish Collective Memory," in Echoes of the Holocaust: Historical Culture in Contemporary Europe, ed. KlasGöran Karlsson and Ulf Zander (Lund: Nordic Academic Press, 2003), 146.

8 Ibid., 168-69.

9 Murray Gordon, The "New Anti-Semitism" in Western Europe (New York: American Jewish Committee, 2002), 11. 
of Israel-related antisemitism, in terms of both incidents and rhetoric, following the outbreak of the Second Palestinian Intifada in the fall of 2000. This tsunami of attacks on Jews, primarily in Western Europe, sparked a lot of interest in "new" antisemitism, and a host of articles and books on the topic were published at the time. ${ }^{10}$

Rage at Israel was channeled into attacks on local Jews and Jewish communities all over Europe, when haters of Israel, consciously or unconsciously, conflated the Jewish state and Jews, wherever they lived. In that way, Jews in Europe were considered legitimate targets and attacked in response to escalating violence in the Middle East. Holocaust terminology was also inverted and used against Israel and Jews. For instance, Nobel Prize laureate José Saramago compared Ramallah to Auschwitz. Israel was routinely accused of carrying out a genocide, whereas Israeli security concerns were mocked, and lethal attacks on Israeli civilians were minimized or exculpated. ${ }^{11}$ Many Jews were shocked by this development, and especially religious Jews changed their way of life in order to keep safe from attacks. Hiding one's Jewish identity became routine, and security at Jewish sites such as synagogues and community centers was upgraded-sometimes with detrimental costs to the small, local Jewish communities. Many Jews also felt a sense of abandonment, since Western European governments were slow to react to the explosion of antisemitism, sometimes even denying it or justifying it as merely a venting of justified frustration at Israeli aggression. ${ }^{12}$

The majority society's widespread silence in the face of this wave of antisemitic attacks was to a large degree due to its political dimension and the connection to the state of Israel. The Jewish state is far from popular in Europe, because of its policies vis-à-vis the Palestinians and the way the IsraeliPalestinian conflict is depicted in the media. This widespread support and sympathy for the plight of the Palestinians - seen as innocent, oppressed victims of Israeli aggression by many in Europe-made many public figures, politicians, reporters, and intellectuals reluctant to condemn Israel-related antisemitism, especially among immigrants. They were afraid that condemning

10 See, for instance, Hillel Halkin, "The Return of Anti-Semitism," Commentary, February 2002, https://www.commentarymagazine.com/articles/the-return-of-anti-semitism; Ron Rosenbaum, ed., Those Who Forget the Past: The Question of Antisemitism (New York: Random House, 2004); and Paul Iganski and Barry Kosmin, eds., A New Antisemitism? Debating Judeophobia in the 21st Century (London: Profile Books, 2003).

11 Gordon, Western Europe, 3.

12 Ibid., 11. 
antisemitic incidents and rhetoric fueled by Israeli policies might be interpreted as support for those very policies, and some even could not see past their own antipathy toward Israel in order to realize that the attacks on local European Jews were not defensible or justified. Furthermore, there was a fear that criticizing antisemitism among immigrants might fuel racism against already marginalized groups. Needless to say, this dilemma was not facilitated by the fact that there is no consensus on the issue of what constitutes legitimate criticism of Israel as opposed to antisemitism masquerading as criticism of Israel. Abraham Foxman, then national director of the Anti-Defamation League, was one of those who tried to draw such a distinction. He made his position clear that far from all criticism of Israel is antisemitic but that modern antisemitism often employs the language of anti-Zionism. Furthermore, he pointed out that anti-Zionists who are antisemites claim that the Jews, unlike all other nations in the world, do not have the right to a state of their own, that there is no connection-historical, religious, or cultural-between the Jewish people and the Land of Israel, and that the state of Israel is illegitimate and needs to be dismantled. ${ }^{13}$ A few of the more extreme, but rather vocal, supporters of Israel would be quick to label any and all critics of Israel as antisemites or selfhating Jews. Dug down in the other trench, other would-be extremists ardently clamored for the position that there is no such thing as "new," or Israel-related, antisemitism, only legitimate criticism of an illegitimate state. ${ }^{14}$

The roots of this form of antisemitism are to be found in the Soviet Union already in the 1950s. Even though antisemitism was illegal and officially no longer existed in the Soviet Union, targeting Israel was a part of Stalin's anti-Jewish campaign as well as his foreign policy in the Middle East, where he tried to win Arab favor and dislodge British and French imperial holds over the region. In their attacks on Israel, Soviet authorities and propagandists made ample use of classic antisemitic stereotypes and tropes common in prerevolutionary Russia. The comparison between Israel and Nazi Germany can also be traced back to the Soviet Union in the 1950 s. $^{15}$ In the decades that followed, the accusation that Israel is the new Nazi Germany spread both to the Middle East and left-wing circles in the West, where it grew in popularity. It is a

13 Abraham H. Foxman, Never Again? The Threat of the New Anti-Semitism (New York: HarperCollins, 2003), 17.

14 Michael Berenbaum, ed., Not Your Father's Antisemitism: Hatred of the Jews in the 21st Century (St. Paul: Paragon House, 2008), 289.

15 Stauber, "New Antisemitism,” 13-14. See also Arnold Forster and Benjamin R. Epstein, The New Anti-Semitism (New York: McGraw-Hill, 1974). 
compelling rhetorical image-the victim becoming the perpetrator-that lends itself well to enraged speeches and political cartoons. Antisemitism scholar Peter Pulzer blames such demonizing of the State of Israel for creating an "antisemitic atmosphere," and when that image spread from Soviet and Arab propaganda to left-wing circles to finally reach parts of the mainstream media and academia, it brought that atmosphere with it. ${ }^{16}$ Murray Gordon of the American Jewish Committee concurs, and he notes that these denunciations of Israel "have given rise to much of the Judeophobia that plagues Western Europe today. A close fit has developed between the demonization of Israel they preach and antisemitism." ${ }^{17}$ Murray also notes that many on the left, intellectuals, activists, academics, and politicians, deny the rise of "new" antisemitism altogether. Their reaction to the rise in attacks against Jews in Europe in the last fifteen years has often been to claim that this is due only to Israeli aggression and not a sign of antisemitism per se. The State of Israel is to blame, and it needs to end its occupation of Palestinian lands or cease to exist. When it does, antisemitism will automatically disappear. ${ }^{18}$

\section{THE MIDDLE EAST AS AN INCUBATOR FOR ANTISEMITISM}

As noted above, the perpetrators of the lion's share of attacks against Jews in Europe today have roots in the Middle East. They are far from always Islamists or even particularly religious but motivated to lash out against local Jews as symbolic representatives of Jews elsewhere, more specifically in Israel. Such attacks are rarely planned but rather spur-of-the-moment incidents when spotting someone identifiably Jewish in the street. ${ }^{19}$ The more serious, and lethal, attacks that require planning and organization, like the ones carried out in France and in Denmark in later years, were, however, carried out by perpetrators who were ideologically motivated Islamists. It is generally agreed that antisemitism historically has not been a grave concern in the

16 Peter Pulzer, “The New Anti-Semitism, or When Is a Taboo Not a Taboo?," in Iganski and Kosmin, A New Antisemitism?, 97-112. See also Alain Finkelkraut, "In the Name of the Other: Reflections on the Coming Anti-Semitism," Azure, no. 18 (Fall 2004): http://azure. org.il/article.php?id=211; Roni Stauber, "Anti-Zionism as an Expression of Judophobia after the War," Masua, no. 31 (1993): 37-53; and Pierre-André Tauguieff, Rising from the Muck: The New Anti-Semitism in Europe (Chicago: Ivan R. Dee, 2004), 97-100.

17 Gordon, Western Europe, 13.

18 Ibid., 10. For one example cited by Gordon, see Tony Judt, "Goodbye to All That?" The Nation, December 16, 2004, https://www.thenation.com/article/goodbye-all.

19 Stauber, "'New Antisemitism," 6. 
xvi $\mid$ Introduction: The Continuity and Change of Antisemitism

Muslim world, especially not compared with the situation in Europe, and that anti-Jewish sentiments have intensified as a consequence of the Arab-Israeli conflict. Furthermore, it is clearly the case that the number of antisemitic incidents in Europe rises whenever the Israeli-Palestinian conflict escalates, fed by both televised images from the Middle East and antisemitic incitement in the public discourse in the Muslim world. ${ }^{20}$ Nevertheless, as historian Roni Stauber points out, the claim that Islamist terror attacks against Jewish targets are merely a form of retaliation for Israel's actions - "The Jews must pay" - is contradicted by both the statements and deeds of these Islamist groups. ${ }^{21}$

The Muslim world, and especially Islamists such as the Muslim Brotherhood, Hamas, Hezbollah, al-Qaeda, ISIS, the Iranian regime, and others, have clearly absorbed antisemitic tropes and myths exported from Europe that were absent from the Middle East before the era of European colonization of the region. This is why so many old, debunked European antisemitic myths have been recycled and are now to be found in the Middle East. ${ }^{22}$ Even the blood libel-that is, the lie that Jews kidnap and ritually murder Christian children in order to use their blood to bake matzah for Passoverhas found its way to the Arab world, where the Saudi paper Al-Riyadh tweaked it into a story about how Israelis kidnap and murder Muslim children and use their blood to bake oznei Haman, the pastries eaten on the holiday of Purim. ${ }^{23}$ Also, The Protocols of the Elders of Zion has found a new lease on life in the Muslim world. The Protocols is an antisemitic forgery purporting to be documentation of a Jewish plan for world domination that was first published in Russia in 1903. The Times published an article in 1921 proving beyond any doubt that The Protocols was in fact a forgery, but that did not stop Adolf Hitler and the Nazis from claiming that it was a reflection of the genuine truth. ${ }^{24}$ After the Second World War, however, The Protocols had few readers in Europe, but in later years it has experienced a revival in the Middle East. In 2002, The Protocols was adapted to television in a forty-one-episode Egyptian series called Knight

20 Foxman, Never Again?; Jonathan Sacks, “A New Antisemitism?, in Iganski and Kosmin, A New Antisemitism?, 39-40; and Robert Wistrich, "Muslims, Jews and September 11: The British Case," in Iganski and Kosmin, A New Antisemitism?, 180.

21 Stauber, "New Antisemitism," 12. See also Martin Kramer, "The Jihad against the Jews," Commentary, October 1994, 38-42.

22 Berenbaum, Not Your Father's Antisemitism, xix.

23 “Saudi Government Daily: Jews Use Teenagers' Blood for 'Purim' Pastries,” MEMRI Special Dispatch, no. 354, March 12, 2002.

24 For more on The Protocols, see Esther Webman, ed., The Global Impact of "The Protocols of the Elders of Zion": A Century-Old Myth (London: Routledge, 2011). 
without a Horse, which was aired on twenty-two Arabic-language channels during Ramadan. This way, an antisemitic forgery that never had a particularly large readership received a mass audience, and unlike in Europe when The Protocols was first published, there is no one willing to go on record in public to point out that the series was based on an antisemitic lie. ${ }^{25}$

\section{ANTI-ANTISEMITISM AS A MEANS TO AN END}

In the antisemitic discourse emanating from the Muslim world, we see, then, how the "new" antisemitism focusing on Israel takes on the content of the "old" antisemitism of Christian and racist Europe. Antisemitism focusing on the State of Israel is by necessity "new" in the sense that the State of Israel was established only in 1948, whereas antisemitism has been around for some two millennia. At the same time, however, there are many aspects of this supposedly "new" antisemitism that bear the hallmarks of the "old." It is perhaps more illuminating to view antisemitism as old, perhaps even the "longest hatred" in Wistrich's words, but as a hatred that renews itself in every age and knows how to adapt in every situation so that it may always remain relevant, no matter the time, place, or context.

At the same time, it can retain elements from previous phases, and some older aspects can endure or even come back under the right circumstances. That is why today, when the West is more secularized, the religious charges against the Jews for deicide and host desecration are less popular, because people care less about religion. In the nineteenth century, antisemitism was racist because race was a prime category of thinking and ordering the world. Jews were considered aliens disturbing the racial harmony of the nation. Today, prejudice against Jews can come cloaked in the high-minded language of universalism and human rights. A hundred years ago, Jews were accused of spreading secularism, and today they are vilified for primitive and patriarchal religious practices. Another popular accusation today is that Jews, especially in Israel, are too nationalistic - a sin that was a virtue a century ago when Jews were accused of being too cosmopolitan. So, even though religion and racism are not important driving forces behind contemporary antisemitism, components of this antisemitism still endure from previous eras. One such component is the idea that the Jews have an improper influence, even

25 Richard S. Levy, "The Migration of Discredited Myths: The Wandering Protocols," in Berenbaum, Not Your Father's Antisemitism, 178-79. 
control, over the media, financial markets, and politicians. The only difference is that today many proponents of this antisemitic trope prefer to talk about the "Israel lobby" or "Zionist influence" instead of "the Jews," but this is merely a play with words - a dog whistle for antisemites. ${ }^{26}$

From the Left, accusations of antisemitism have almost always been met with outrage. Most left-wing politicians and intellectuals are self-proclaimed and vocal anti-racists, and for them the concept of antisemitism is truly abhorrent. It is also true that most people on the left are quick to recognize and condemn antisemitism when it comes in the form of right-wing racist propaganda but have developed a blind spot to antisemitism within their own ranks or among immigrant groups. It becomes especially hard, all but impossible, for them to recognize antisemitism if it comes cloaked as criticism of Israel. In fact, accusations of antisemitism directed at left-wing politicians or intellectuals are routinely met with the counteraccusation that the claim is made in bad faith in order to silence criticism of Israel. Sociologist David Hirsh calls this phenomenon "the Livingstone formulation" after the former mayor of London Ken Livingstone, who used to employ it. ${ }^{27}$

This reluctance of the Left to face and deal with antisemitism under the guise of anti-Zionism has drawn criticism in the last fifteen years or so, not only from Jewish organizations but also increasingly from the Right. Several right-wing writers, journalists, pundits, and politicians, both in Europe and in the United States, have embraced Israel and routinely condemn antisemitism. Despite this, the majority of Jews on both sides of the Atlantic, fearing the Greeks even when they bring gifts, have been hesitant to endorse such politicians and other public figures. Indeed, much of this right-wing support for Israel and outspokenness against antisemitism has been more of a political means to an end than actual worry about the well-being of Jews. Many rightwing supporters of Israel see the Jewish state as the bulwark in a clash of civilizations between the West and Islam, and they use antisemitism as a weapon to attack and vilify Muslim immigrants in Europe and in America. In the last few years, Jewish skepticism regarding the sincerity of this right-wing support has proven to be well founded. Several of the extreme right-wing populist parties in Europe that are most vocal in their support of Israel also have several antisemites in their ranks, and the 2016 US presidential elections also brought

26 Denis MacShane, Globalising Hatred: The New Antisemitism (London: Weidenfeld and Nicholson, 2008), 124-26.

27 David Hirsh, “The Livingstone Formulation,” Engage, April 29, 2016, https://engageonline. files.wordpress.com/2016/04/livingstone-formulation-david-hirsh.pdf. 
forward troubling antisemitic statements from prominent right-wing voices in America. And when the very same people who were so vocal about Muslim and extreme left-wing antisemitism are faced with such right-wing antisemitism, they choose not to condemn but rather to minimize or exculpate-much in the same way that they criticize the Left for treating antisemitism within their own ranks and among immigrants. The Livingstone formulation has even been reversed, to deny any antisemitism on the grounds that the accused support Israel.

In other words, the hatred of Jews as an idea is almost universally repugnant in the West, but most politicians and intellectuals will speak out against it in practice only if it is politically expedient and serves their own ideological goals. The Jews, in the meantime, are left between the Scylla and Charybdis of two forms of antisemitism with very few true allies. At such a time, a volume like this is more relevant than ever.

\section{THE OUTLINE OF THIS BOOK}

This book is composed of chapters on various aspects of antisemitism today, offering concentrated, in-depth analyses of situations and phenomena touched on above. Each chapter forms a piece in a large mosaic giving a bigger picture, illustrating the state of affairs in the beginning of the twenty-first century. The first chapter, written by Lars Dencik and Karl Marosi, offers a sociological analysis of the phenomenon of contemporary antisemitism in Europe. This chapter studies eight European countries, investigating how the level of antisemitism as registered in national populations relates to the perception of antisemitism by the Jewish population in the same country. Furthermore, Dencik and Marosi empirically identify distinct aspects of antisemitism, deconstructing the concept of antisemitism and breaking it up into three kinds of objectively differently based and composed antisemitisms: classic antisemitism, Israel-derived antisemitism, and Enlightenment-based antisemitism. This chapter also elaborates on some more general implications for the understanding of the character of antisemitism in contemporary Europe, and in light of that, it presents some perspectives on the development of the three distinct antisemitisms in contemporary Europe.

In her chapter, Natalia Sineaeva-Pankowska illustrates the process facing post-communist countries that are forced to revise their history of the Holocaust, as mentioned above. She analyzes how, after 1989, post-communist countries such as Poland and Moldova have been faced with the challenge of 
xx $\mid$ Introduction: The Continuity and Change of Antisemitism

reinventing their national identity and rewriting their master narratives, shifting from a communist one to an ethnic-patriotic one. In this context, the fate of local Jews and the actions of Poles and Moldovans during the Holocaust have repeatedly proven difficult or even impossible to incorporate into the new national narrative. As a result, Holocaust denial in various forms initially gained ground in post-communist countries, since denying the Holocaust or blaming it on someone else, even on the Jews themselves, was the easiest way to strengthen national identities. In later years, however, Polish and Moldovan paths toward re-definition of self have taken different paths. At least in part, this can be explained as a product of Poland's incorporation in the European unification project, while Moldova remains in limbo, in terms of both identity and politics - between the Soviet Union and Europe, between the past and the future.

Irena Cantorovich also analyzes the tension between different, indeed clashing, historical narratives in Eastern Europe. During World War II, members of the local population in German-occupied territories collaborated with the occupiers, including in the implementation of the Final Solution. These collaborators were motivated by antisemitism, greed, and career advancement, among other factors. In the Soviet Republic of Ukraine, there was an additional motive: the ambition to regain independence, fueled by hatred of the Soviets who had taken it. Ukrainian nationalists considered all means legitimate, even collaborating with the Germans in the murder of Jews, in order to persuade the Germans to help reestablish an independent Ukraine. However, even when those who called themselves freedom fighters and partisans realized that the Germans had no intention of fulfilling their dream, they did not cease their involvement in the Holocaust, continuing to regard Jews as hated representatives of the Soviets. To this day those Ukrainians and their supporters see them as heroes and patriots who risked their lives for the independence of their country. On the other hand, in Jewish memory, they are perceived as collaborators and murderers. Cantorovich discusses attitudes of Ukrainian nationalists toward the Jews during the war and contemporary attempts to honor collaborators in Ukraine as well as abroad.

Michael Whine maps the rise of the radical Right in Europe and analyzes its attitude to the Jewish population. Whine is careful to note that the radical Right should be differentiated from other trends on the far right. The radical Right includes the emerging anti-immigrant populist and social movements, which are racist, are sometimes antisemitic, and may have neoNazi origins, but which may also have rejected them. The extreme Right 
includes neo-Nazis, neo-Nazi skinheads, autonomous nationalists, and Third Positionists, the majority of whom have adopted antidemocratic and sometimes violent means to pursue their ideologies.

The following chapter, written by Michal Navoth, offers an illustration of the development in one of the European countries where the extreme Right has had the largest electoral successes in the last years - namely, Greece. In the wake of the deep economic crisis and the tough austerity measures in Greece, a previously insignificant and marginal movement, the Golden Dawn, has grown to become the country's third-largest party. It stands strong in the polls and elections despite increasing evidence of its involvement in organized violent crimes and its unabashed racist, antisemitic, and neo-Nazi ideology. The voters still flock to the party, since it has managed to capitalize on the anger of the public against the austerity measures — not least by carrying out highly publicized charity work "for Greeks only." The Golden Dawn's ability to achieve and consolidate its present prominent position, despite an unprecedented crackdown undertaken by the Greek authorities since mid-September 2013, is worrisome from the perspective of its potential long-term influence on Greek society.

The dramatic rise in antisemitic incidents in the first years of the twentyfirst century led to attempts to combat resurging antisemitism in Europe. A part of this effort was to find a universally agreed-upon definition of what antisemitism is. In her chapter, Dina Porat chronicles the difficulty in navigating academic, cultural, and political concerns in the attempts to develop such a definition. On January 28, 2005, the European Monitoring Centre on Racism and Xenophobia, then based in Vienna, reached a definition of antisemitism that was later prominently referred to at the Organization for Security and Co-operation in Europe Cordoba Conference in June of that year. Since then, many other bodies have advocated its use. The one-page "Working Definition of Antisemitism" evolved as a result of the concerted efforts of a large number of institutes and individual experts. Those efforts lasted for two years (2003-2004), during which time many questions were elaborated regarding both the principles and parameters of the definition. Nonetheless, and despite the definition's proven usefulness in the field, it came under attack. Its detractors seemed to be especially averse to the recognition of the fact that criticism of Israel could sometimes take antisemitic forms.

In his chapter, Günther Jikeli offers an overview of the complex position of Muslim immigrants in Europe today. As noted above, many contemporary antisemitic incidents emanate from this population, but at the same time, Muslim communities in Europe face a number of socioeconomic 
challenges, as well as discrimination, themselves. One in three Muslims in the European Union has suffered discrimination, and Muslim organizations point to mounting fears and anger among the communities about the rise of antiMuslim sentiments. Simultaneously, many young Muslims in Europe exhibit antisemitic attitudes. While polls reveal that only a minority of European Muslims endorse antisemitic views, they also show that the level of antisemitism is significantly higher among Muslims than among non-Muslims. The genesis of antisemitic views cannot be reduced to a single factor. Ethnic or religious identity and interpretations of Islam are significant for some. Here, the use of the term Muslim antisemitism is apt. Others relate their hostility toward Jews to their hatred of the State of Israel. Many use classic antisemitic attitudes that are also widespread in mainstream European society. While discrimination and exclusion of Muslims in Europe is still a reality, this does not seem to be a relevant factor influencing antisemitic attitudes.

The next several chapters explore what Dencik and Marosi call Israelrelated antisemitism in Europe and the difficulty in combating it. Julia Edthofer takes as her starting point the Israel-Gaza conflict of 2014 and explores what the reactions to it can say about Austrian society. The so-called Operation Protective Edge brought about a massive outburst of anti-Israeli protest and was followed by a marked rise of antisemitic incidents all over Europe, including in Austria. Many rallies were organized by Muslim organizations or attended by a considerable number of people identifying as Muslims, which sparked media discussions about the rise of an Islamized antisemitism and social tensions within Europe's multicultural migrant societies. However, an analysis of the debates shows that rather than tackling the problem, the events were often either used for anti-Muslim arguments and a deflection of Austrian antisemitism or downplayed as a supposedly "anti-racist" reaction to the anti-Muslim bias in the media coverage. This chapter seeks to illustrate such ambivalent entanglements of antisemitic and anti-Muslim resentment. It is argued that notwithstanding the extensive discussions about the necessity to fight "Muslim antisemitism," the core of new antisemitism (namely, the "colonial framing" of the Israeli state) is a view widely shared not only by Muslim actors but also by the Far Right, the Far Left, and-albeit lacking the conspiracy-theory component-even mainstream Austrian society.

Kristin Wagrell also uses Operation Protective Edge in 2014 as the basis for her study of antisemitism in the campaign for the Swedish general elections that same year. Several candidates from various parties were caught making antisemitic statements or comments on Facebook and in other contexts. 
Even though these candidates were eventually forced to resign and drop out of the electoral race, the complacency and apologetic attitude that met most of them speaks to a deeper problem in the Swedish political discourse. There is a widespread inability, or perhaps unwillingness, to recognize antisemitism when it does not present itself in the form of neo-Nazism. This became even clearer when contrasted with the shock and condemnation that met the sweeping electoral gains of the extreme right-wing Sweden Democrats. As long as self-avowed anti-racists allow themselves and others to employ antisemitic language, especially in the name of defense of the downtrodden, it won't be possible to combat the problem of antisemitism in any meaningful way.

In his chapter, Mathan Ravid stays in Sweden, but he shifts the focus away from politics to the media. In the beginning of the twenty-first century, Mohamed Omar was a respected poet, cultural journalist, and intellectual. In January 2009, however, he became Sweden's most outspoken supporter of Islamist movements, as well as the Iranian and Syrian regimes. His hate propaganda was directed almost entirely against Israel, Zionism, and the Jewish people in general, focusing on alleged Jewish-Zionist conspiracies and Holocaust denial. Omar was successful in creating a platform for those sharing his radical views, regardless of political affiliation, demonstrating how antisemitism can serve as a bridge between different and even opposing ideological groups: Islamist, radical Left, and Islamophobic extreme Right. Most mainstream Swedish media outlets and organizations soon stopped giving Omar a platform. However, it took a while for some journalists on the left, notably from the Social Democratic Aftonbladet (Sweden's largest tabloid), to label Omar an antisemite and to marginalize him. It was mainly his association with the Swedish extreme Right that made them change their attitude. Omar's case is an example of how self-proclaimed "critics of Israel" without clear or outspoken links to the extreme Right, who present their notions of "Jewish power and manipulations" in anti-Zionist terminology, are not always condemned or even criticized.

Andre Oboler also focuses on the public discourse and discusses how the terror attack on the satirical magazine Charlie Hebdo in Paris on January 7,2015 , sparked a debate on freedom of speech versus freedom of religion. These two basic values of a democratic society may seem to be at odds, but only when failing to make the distinction between attacks on a religion and attacks on people belonging to that religion. Increased clarity on how to define freedom of religion, freedom from religion, and hate speech on racial or religious grounds will serve to create a consistent approach in combating intolerance in an increasingly multicultural society. 
Liora Hendelman-Baavur also deals with the media, albeit media working under other conditions. In her chapter, she analyzes how, during his two terms as president of Iran (2005-13), Mahmoud Ahmadinejad went further than any of his predecessors in making antisemitic declarations and became internationally infamous for negating the veracity of the Holocaust. Ahmadinejad's statements received much attention from the media and the international community, but the ways in which Iranian media participated in propagating antisemitism and negationism throughout his presidency, especially through the use of the Internet, has not been addressed in any systematic manner. Under Ahmadinejad, antisemitism and negationism became a leitmotif of Iran's foreign policy, and they were systematically endorsed, sponsored, and disseminated online by the state apparatus as a part of the Islamic Republic's hybrid anti-Zionist and antisemitic political agenda. Since his election in 2013, President Hassan Rouhani has distanced himself from his predecessor's rhetoric and has made a U-turn in Iran's public-diplomacy exploitation of antisemitism and negationism. Nonetheless, most of the antisemitic and negationist material produced in the course of Ahmadinejad's presidency continues to be available on the Internet and still forms an undisputed part of Iran's state ideology.

The last two chapters focus on the situation in South America. Adrian Gruszniewski and Lidia Lerner describe how the 1994 bombing of the AMIA Jewish Community Center in Buenos Aires, which killed eighty-five people, as well as the long and scandal-ridden investigation into the deadly attack, still cast their shadow over modern Argentinian politics. The bombing and the controversy surrounding the investigation, as well as the death of Special Prosecutor Alberto Nisman, played a prominent part in the 2015 presidential election. Even though its effects on the outcome are hard to measure, the so-called Nisman case still served to galvanize the central Jewish institutions on the political scene. Thus, this became the first election in which a Jewish issue appeared prominently in a presidential race. Nonetheless, the Peronists did not respond with the kind of antisemitic smear campaigns that have been launched in other Latin American countries, most notably Venezuela. A major reason for this may actually be the memory of the AMIA bombing and other instances of persecution of Jews in Argentina during the country's long years of dictatorship, an important element in the country's human rights movement.

In the last chapter, Lidia Lerner describes how the situation for Jews in Venezuela gradually deteriorated following the election of Hugo Chávez as president. While not concealing their sometimes virulent anti-Zionist rhetoric, Chávez and his government have denied charges of antisemitism. 
However, recent years have witnessed a rise in antisemitic manifestations, including vandalism, media attacks, caricatures and physical attacks on Venezuelan Jewish institutions. The roots of Chávez's antisemitism, and that of his followers, are various: racist, political, opportunistic and, in some cases, religious. Chávez was strongly influenced by the late Norberto Ceresole, an ultra-nationalist Argentinean antisemite and Holocaust denier, who served as his adviser and mentor from 1994. Chávez’s strong links with Iran also play a significant role in his attitude toward Israel and Jews. Following the attempted coup against Chávez in 2002, the level of antisemitism escalated further. Since then, there has been a persistent growth of antisemitic expressions in the speeches and publications of government circles, pro-government organizations, and the Left. The tone is set by Chávez himself, who generally blames the Jews or the Israeli government for perceived historical or contemporary injustices. 
